\title{
Reinforcement religious moderation through entrepreneurship in islamic boarding school as social empowerment function
}

\section{Sarji}

Graduate School of Muhammadiyah University Prof. Dr. Hamka, Indonesia faisalsarji@gmail.com

DOI: $10.18326 /$ attarbiyah.v5i2.135-151

Submitted:

29 Oktober 2020
Accepted:

11 January 2021
Published:

13 January 2021

\begin{abstract}
This study aimed to explain the importance of enhancement religious moderation in Islamic boarding schools in the province of Special Capital Region of Jakarta. Then, it used to analyze the escalation in entrepreneurship and religious moderation. Furthermore, it expected could describe religious moderation and entrepreneurship as instruments of social empowerment. The method used in this research is a case study which intended to capture the phenomenon of religious moderation in Islamic boarding schools in this province through observational data, expert statements, interview's results and document study descriptions. The outcome found in this research that religious moderation can be enhanced by religious knowledge and preserve religious emotions. In addition, entrepreneurship training include business ethics content that could encourages students to connect with various backgrounds of people who require an understanding of moderation. Additionally, the entrepreneurship program can be used as a social engineering devices for Islamic boarding schools to empower people.
\end{abstract}

Keywords: Religious Moderation, Entrepreneurship and Social Empowerment Function. 


\section{INTRODUCTION}

Religious moderation has developed in Islamic boarding schools throughout Indonesia. This is done because Islamic boarding schools in Indonesia have so far been seen as too emphasizing traditional aspects and conservatism that override their ability to develop themselves in modern life (Awwaliyah, 2019). So that the government hopes that with the development of the concept of religious moderation, Islamic boarding schools can bring changes in reducing radical thoughts that can endanger security in Indonesia. In addition, religious moderation is considered to be able to improve people's views on Islam, especially for Indonesian citizens of different beliefs.

Before, the researcher explained the steps to increase religious moderation of Islamic boarding schools in the province of Special Capital Region of Jakarta, here are the following experts' statement of religious moderation in Indonesia:

"... Diversity in Indonesia is different from diversity in other regions because diversity in Indonesia is inclusive. This can be seen from the number of Muslims in Indonesia of 260 million people or $88.2 \%$ who constitute the majority. Therefore, religious moderation would not have been possible if there were no Muslims. "... This fact has caused the amazement of many observers in Europe and America. They wonder why Muslim-majority Indonesia did not become an Islamic state. Meanwhile, there are many countries based on religion in Europe such as Christian, Anglican, Calvinist and Uteran. Religious moderation in Indonesia has been very visible since the beginning of Indonesian independence. Muslims accept four basic principles, NKRI, UUD 1945, Pancasila and Bhineka Tunggal Ika. Historically, religious moderation has also been seen from the absence of obstacles in various fields of life such as public officials, ministers, governors and other positions for non-Muslims. This shows the moderation of Muslims as the majority in this country (Azyumardi Azra)."

"Wasathiyyah is moderation, not in the interests of individuals but also matters of groups, society and the State. Especially nowadays, when various ideas have entered our house without permission and various extreme groups or their opponents have shown their faces accompanied by religious arguments whose interpretation is very far from the essence of Islam. All parties acknowledge the importance of moderation but related to its meaning, purpose and application it is often blurred."

"To implement moderation requires knowledge of the conditions and needs of the community. So religious moderation requires knowledge of religious teachings as well as knowledge of conditions in society. Therefore, the definition of moderation will differ between countries. The basic principles of wasathiyyah for all Muslims are the same, the Almighty divinity, the belief that the prophet Muhammad is a prophet, Qur'an is true and there will be a day later. The key is to have knowledge and nurture religious emotions (Quraish Shihab)." 
These statements show that there is a difference between religious moderation in Indonesia and in other countries. Religious moderation in Indonesia can occur because of the tolerance accepted by Muslims. Wasathiyyah or religious moderation needed so that interpretations related to the nature and arguments in religion did not deviate or mislead. To increase religious moderation requires knowledge of religion and condition of the community in the surrounding environment. Therefore, the application of religious moderation in Jakarta also different from other regions. This is because the circumstances of the advanced and modern Jakarta society are different from those in other cities.

Yasid (2014) declared that as the last divine religion sent down by Allah SWT through the Prophet Muhammad SAW, Islam is perceived to contain moderate teachings in it, which are often known as Islamic Moderation. Islamic teachings not only contain issues of Divinity in religious rituals but also other matters relating to humanity with application in everyday life. Islam is the majority religion adhered to by Indonesian citizens.

Religious moderation is a middle way in the midst of religious diversity in Indonesia. Moderation is an archipelago culture that goes hand in hand, and does not negate each other between religion and local wisdom. Not contradicting each other but seeking a solution tolerantly (Akhmadi, 2019). Religious moderation is a solution to combine religious teachings with local wisdom or national culture. This is done in the hope that it can be understood and accepted by many parties and does not sharpen differences in views that can lead to conflict.

Misrawi (2010) expressed that religious moderation can be interpreted as an understanding that takes the middle way, namely a notion that is neither extreme right nor extreme left. Religious moderation is a concept that is in accordance with the foundation of the Indonesian State, namely Pancasila which is contained in the principle of social justice for all Indonesian people (the fifth principle). It is a fact that religious moderation is an understanding in accordance with Islam and Pancasila. So religious moderation is said and appropriate when applied to conditions in Indonesia.

\section{Principles of Religious Moderation}

Muslims should take a middle path (moderation). Such a view makes it easy 
for Muslims to practice their religion. Because in essence, Islam is indeed a religion that makes it easy for people to carry out the commands of Allah and His Messenger (Kementerian Agama RI, 2012). The principles of religious moderation in Islam consist of Justice ('Adalah), Islam promotes justice for all parties. Many verses of the Al-Qur'an show this noble teaching. Without promoting justice, religious values feel dry with no meaning, because justice is a religious teaching that directly touches the lives of many people. Without it, prosperity and well-being will only be wishful thinking (Maarif, 2017). Fair law is a basic demand for every structure of society. Fair law guarantees the rights of all walks of life and individuals in accordance with the general welfare, accompanied by the application of the behavior of its various regulations (Syafrudin, 2009). Balance (Tawazun), as for the meaning of balance as human nature, body, hearing, sight, heart and so on is evidence that can be felt directly by humans, when there is no balance, the body will hurt. At a more detailed level, the forms of balance in Islam can be classified into various kinds of religious life institutions as follows: Theological balance, the balance of religious rituals, the balance of morality and character and Balance of Tasyri'i processes (legal formation). Tolerance (Tasamuh), as a religion that is holy in faith and sharia. Islam will not pollute it by mixing with other faiths and sharia. And this is not a form of intolerance, because the realm of tolerance is respect, not justification and following (Yahya, 2017). Tolerance is one of the principles of religious moderation. This can be exemplified by taking part in protecting places of worship of followers of other religions from acts of terrorism, but that does not mean following these religious ceremonies.

\section{Types of religious moderation}

Purwanto, Qowaid, Ma'rifataini and Fauzi (2019) mentioned that moderation developed in Islam includes several things: Akidah moderation, moderation in the field of faith as taught by Al-Asyariah moderation, namely moderation between the very rational Muktazilah and the Salafiyah who put forward the text without using rationality. Moderation of Islamic Law, dialectics between text and reality are in line in issuing a law. The existing law makes it easy for humans without forgetting the naqli argument. Interpretation Moderation, the interpretation used is the product of a blessed moderate interpretation, where the product of interpretation is in accordance with Islamic values 
which still takes into account the pluralistic conditions of a pluralistic and heterogeneous society. Moderation of Islamic Thought, this is shown by Islamic thought which promotes tolerance in terms of differences, openness to accept diversity, both in various schools and religions. Moderation of Sufism Moderate, moderate Sufism is shown by building a life full of happiness, such as: qalbiyah happiness, namely by means of knowledge through good morals, and physical happiness with health and fulfillment of material needs.

\section{Indicators of Religious Moderation}

Amin (2014) stated that Indicators that illustrate the existence of religious moderation are as follows: Flexibility and Renewal, one of the indicators of moderation in Islamic law is its flexible character, can accept renewal, can adapt to the needs of the times and accommodate emerging issues, and it is an implementation of the Islamic teachings rahmatan lil alamin. Convenience (Al-Taysir), Islam does not only recognize emergency conditions commonly experienced by humans as cases that cannot be avoided and then give laws based on certain conditions. Rukhsah facility, rukhsah is generally defined as relief. In terms of terminology, Rukhsah is defined as things that cannot be done but can then be done by a mukallaf for certain reasons that are recognized by religion.

\section{Religious Moderation in Islamic Boarding Schools}

Various acts of terror are often associated with Islamic boarding schools. Islamic boarding schools are considered to have generated radical thoughts. Even though there are two things that cause the radicalization process in Islamic boarding schools. First, the intellectual network carried out by modern Islamic boarding schools originates from the Middle East, which is hard-tempered, militant and radical, especially Wahabi teachings that were brought literally to the archipelago. Purification is a tangible product of Wahabism's intellectual network in the form of eradicating superstition, bid'ah and khurafat. In the subsequent process, this intellectual network expanded, not only based on the Wahhabism, but also adopted the radical ideology of a number of intellectuals; such as Hasan al-Bana, Al-Maududi, Sayyid Qutb, Hasan Turabi, and others. That is why, the psychology of radicalism that is roiling in the Middle East is actually being practiced in this country as a noble religious struggle. 
Second, exclusive and dogmatic religious teachings have created hostility towards groups outside of it. The term Zionist-Kafir seems to be transformed into a religious consciousness to fight it in any form. Coupled with the ideology of jihad, which is understood as a war against the Zionist-Kafirs, has added to a line of radical attitudes. So that any acts of violence carried out by the Ummah to destroy the Zionist-Kafir, which they call the enemies of Islam, are the most noble religious struggles (martyrdom). Basically, this kind of teaching is not purely an authentic awareness of the Indonesian Islamic community, but rather the influence of intellectual and ideological networks brought from the Middle East (Zada, 2007).

Mahdi (2013) said that Islamic boarding schools as educational institutions have contributed significantly to the emergence of discourse on national character education. Life in an Islamic boarding school trains the independence of students who are entrusted by their parents to study. The image of a positive Islamic boarding school can have a real impact because most students who study come from all corners of the region in Indonesia. Maesaroh and Achdiani (2017) mentioned that Islamic boarding schools can be the pioneers of change that reach all regions in Indonesia. Islamic boarding schools in the modern era have a duty to maintain their existence as educational institutions, guardians of values and norms as well as centers of religious activities. In order to survive with all the times, of course, Islamic boarding schools are expected to continue to improve skills for students and other residents.

Fathoni and Rohim (2019) concluded that generally, people think that Islamic boarding schools are only places to study religion. Whereas Islamic boarding schools have potential in the fields of health, technology development, environmental restoration and the most important sector is economic empowerment for the surrounding community. Many Islamic boarding schools have grown and continued to develop in Indonesia because they have advantages. This is what makes Islamic boarding schools chosen by parents as educational institutions for their children. Each Islamic boarding schools offers various programs that embody student independence. One of the things that can encourage student independence is entrepreneurship.

Saragih (2017) expressed that Entrepreneurship is a creative and innovative ability, is observant at seeing opportunities and is always open to any positive input and 
changes that are able to bring the business to continue to grow and have value. Meanwhile, Timmons and Spinelli (2008) stated that Entrepreneurship is a way of thinking, analyzing, and acting based on a balanced business opportunity, holistic approach and leadership. The things that most motivate a person to enter an entrepreneurial career are the personal attributes and personal environment. Entrepreneurial interest is influenced by the potential of entrepreneurial personality and the environment (Alma, 2010).

Entrepreneurship education (entrepreneurship) in Indonesia is still not getting enough attention, both by the world of education, society, and the government (Aprijon, 2013). Support for entrepreneurial development in Islamic boarding schools can help the government ease the burden on the economy. The progress of Islamic boarding schools in developing entrepreneurship based on Islamic guidelines is expected to bring prosperity to its residents, such as teachers, employees and students. So that they can avoid radicalism because of economic factors.

Entrepreneurship has several advantages and disadvantages. The weaknesses of being an entrepreneur are (1) uncertain income, (2) hard work with unlimited time, (3) low quality of life before they succeed and (4) big responsibility because there are many decisions that must be taken even though they have not mastered the problem. While the advantages of being an entrepreneur are (1) open opportunities to achieve goals, (2) open opportunities to demonstrate full potential, (3) open opportunities to obtain maximum benefits and benefits, (4) open opportunities to help society with concrete efforts, and (5) open the opportunity to become a boss (Alfianto, 2012).

The benefits if someone who is entrepreneurial are as follows: (1) Provides opportunities and freedom to control one's own destiny. (2) Providing opportunities for change, business people find ways to combine their forms of concern for various economic and social problems with the hope of living a better life. (3) Providing opportunities to reach their full potential. Having one's own business gives power, spiritual awakening and enables entrepreneurs to follow their own interests or hobbies. (4) Having the opportunity to achieve maximum profit. (5) Having the opportunity to play an active role in society and get recognition for his efforts. (6) Having the opportunity to do something you like and feel good about doing it.

Suryana (2006) concluded that the factors that influence a person's entrepreneurial 
spirit include self-confidence, optimism, discipline, commitment, initiative, encouragements, leadership, like challenges, responsibility, and human relationships. Ghofur, Asiyah and Shofiyullah (2015) declared that an important role that makes a plus in entrepreneurship training in the Islamic boarding school's environment is that they not only get entrepreneurial knowledge but also get Islamic values and role models that they get while being students at the Islamic boarding school. This can be a capital for students to become entrepreneurs.

In general, Islamic boarding schools can be classified into two, such as salaf or traditional boarding school and khalaf boarding school or modern boarding school. Salaf of Islamic boarding schools in their educational activities are solely based on classical or old teaching patterns in the form of yellow book recitation with traditional learning methods and have not been combined with modern educational patterns. Meanwhile, the khalaf or modern boarding school are which in addition to preserving the main elements of the boarding school but also incorporating modern elements marked by the classical or school system and the existence of general science material in its curriculum content (Kementerian Agama, 2003).

In general, it can be said that the characteristics of the pesantren lie in its components. The components or characteristics of Isla mic boarding schools have characteristics, such as: 1) cottage, 2) mosques, 3) students, 4) teaching of classical Islamic books, and 5) there is a kyai (Aly, 2011). Muhaimin (1992) concluded that the purpose of the presence of Islamic boarding schools is divided into two parts, including: (1) Special objectives, preparing students to become pious people in the religious knowledge taught by the kyai concerned and to practice them in society. (2) General Objectives, Guiding students to become human beings with Islamic personalities who with their religious knowledge the students are able to become Islamic preachers in the surrounding community through their knowledge and practices. Wahidah (2015) declared that Islamic boarding schools should be able to activate the following functions: 1) Islamic boarding schools as educational institutions that transfer religious knowledge (tafaqquh fi al-din) and Islamic values (Islamic values), 2) Islamic boarding school as religious institutions that exercise control social, and 3) Islamic boarding school as religious institutions that carry out social engineering or community development. Related to the function of Islamic boarding 
school as religious institutions that exercise social control, Islamic boarding school are expected to be able to build better communities around them in terms of worship, education, economy and behavior. So that the community around the boarding school is affected by the existence of the boarding school.

Romadlan (2019) mentioned that social engineering is a planned social change, seeking to change society as desired. Social engineering can be carried out by Islamic boarding schools to encourage change for the surrounding community. These changes can be in the form of welfare in the economy or social changes through religious activities to improve community behavior. Islamic boarding schools can become pioneers of change for the surrounding community with superior programs involving students and boarding school administrators.

Based on the research background above, the gap between this study and previous research is the existence of entrepreneurship as a variable that supports religious moderation in Islamic boarding schools and is expected to be in line with the social empowerment function variable. Meanwhile, other studies mostly compare religious moderation with the prevention of radicalism. Therefore, the novelty in this study is the support of entrepreneurial variables and the function of social empowerment in encouraging religious moderation in Islamic boarding schools. Next, the research problems shown in this study are: the steps to increase religious moderation in Islamic boarding schools in DKI Jakarta province; (2) the role of entrepreneurship in increasing religious moderation; (3) escalation of religious moderation through entrepreneurship as a function of community socio-economic empowerment.

\section{METHOD}

The method used in this research is a case study method with a qualitative approach. A case study is an empirical inquiry that investigates phenomena in a real-life context, where the boundaries between the phenomenon and the context are not clearly visible and where multiple sources of evidence are utilized (Yin, 2013). This method is considered suitable for researching the phenomenon of religious moderation developed in Islamic boarding schools in accordance with the background of this study, especially in Jakarta.

Moleong (2010) expressed that a qualitative research approach is a research approach 
that produces descriptive data in the form of written or spoken words from people and observable behavior. The qualitative approach is assumed to be in accordance with the data to be used in this study and the appropriate instruments to answer the problem formulations in this study.

The population is the entire population that is intended to be investigated. While the sample is a number of people whose numbers are less than the total population (Sutrisno, 2005). The population in this study consisted of 100 Islamic boarding schools in Jakarta (attachment 1). Meanwhile, the sample used in this study refers to Arikunto's statement which states that if the subject is less than 100 , it is better to take all of them so that the research is a population study. Furthermore, if the number of subjects is large, $10 \%-15 \%$ or $20 \%-25 \%$ or more can be taken. Furthermore, researchers will select ten or $10 \%$ of the population of Islamic boarding schools in Jakarta to be observed (Arikunto, 2016).

\section{Table 1. Research Sample}

\begin{tabular}{ll}
\hline No. Islamic Boarding Schools in Jakarta \\
\hline 1 & PP. Minhaajurrosyidin \\
2 & PP. Islam Hubbul Wathon \\
3 & PP. Nurul Aini \\
4 & PP. Tahfid Alquran dan Sains Nurani \\
5 & PP. Khodijatul Qubro \\
6 & PP. Al- Kautsar Manggis \\
7 & PP. Nurul Ibad \\
8 & PP. YAPIS Al Oesmaniyah \\
9 & PP. Syarif Hidayatullah \\
10 & PP. Azziyada \\
\hline
\end{tabular}

Research instruments are tools that can be used to collect research data or information. The instruments used in this study were adjusted to answer the problem formulation in this study as follows (Sanjaya, 2011). observations, document study, interview and expert statements. The data collected in this research is based on the results of the observation checklist, interview descriptions and relevant theoretical descriptions.Meanwhile, the data source used is the primary data source (direct) obtained 
from the observation sheet, the results of the interviews and the quotes of the relevant theories with the problem formulation in this study. The data collection techniques used in this study

Data analysis technique begins with: (1) Data collection, namely processing and preparing data for analysis. (2) Data reduction, namely compiling interview transcripts, scanning material, typing field data or selecting and compiling the data into different types depending on the source of the information. (3) Presentation of data, namely classifying, directing, removing unnecessary and organizing data that has been reduced to provide a sharper picture of the results of observations into themes. Then form a matrix, network, cart, or graphic. Whereas in qualitative research, data presentation is carried out in the form of brief descriptions, tables, charts and relationships between categories. By presenting the data, the data is organized and structured so that it will be easier to understand. (4) Drawing conclusions, namely by making conclusions and verification steps. The initial conclusions put forward are still provisional and will change if no solid evidence is found to support the next stage of collection. Conclusions in qualitative research can answer the formulation of the problem formulated from the start.

\section{RESULTS AND DISCUSSION}

Among ten samples of Islamic boarding schools, only one Islamic boarding school or $10 \%$ have yet to determine which form of religious moderation needs to be applied. Observation made with the rubric from Amin (2014) with indicators of flexibility and renewal, convenience and rukhsah. Flexibility and renewal consists of a character that is flexible, can accept updates, can adapt to the needs of the times and accommodate emerging issues. Meanwhile, related to convenience consists of recognizing emergency conditions commonly experienced by humans and giving laws based on certain conditions. Meanwhile, the last indicator of rukhsah facilities is giving relief for certain reasons.

Religious moderation actually existed in Indonesia for a long time. However, religious moderation in Indonesia realized because Muslims who form the majority of the population in Indonesia. Muslims who are the majority did not demand the establishment 
of a state based on their religion but accept differences and diversity voluntarily. It can be seen from various aspects of life. One of the basic things is related to a person's job or position. Non-Muslim residents are not prohibited or prevented from holding an important position in this country. This fact has become an indicator that Indonesia has implemented religious moderation. Furthermore, Jakarta as capital of the provinces and the State also had a non-Muslim governor, namely Basuki Tjahaja Purnama (Ahok). Thus, Jakarta has implemented religious moderation.

The basic principles of religious moderation for Muslims approach the pillars of faith. As said by the expert above, Muslims must moderate in carrying out their religion. Meanwhile, the key to implementing religious moderation is having knowledge and maintaining religious emotions. Having knowledge about religion can be categorized as having several levels of practicing religion, minimum, medium and maximum. Therefore, Muslims have no right to judge if there is a person or individual who practices his religion minimally or moderately and optimally. Muslims are not encouraged to go over the edge or to the extreme because it is the beginning of dangerous radicalism.

Then maintaining religious emotions by believing. Moslem must believe that Islam is $100 \%$ true for her or himself (internally). But they prohibit to blame or judge that other people or other people's beliefs are wrong (externally). So that there is tolerance in the diversity of the peoples and intimacy between the people as it has been. In increasing religious moderation, Islamic boarding schools in Jakarta are expected to provide direction to their students that Jakarta, which is the capital of the State and the province, must realize that Indonesia is based on Unity in Diversity, Pancasila, the's 1945 Constitution and in the form of the unitary Republic of Indonesia. So the issues related to the formation of an Islamic State in Indonesia are not justified. Because since the inception of the State of Indonesia, it has been based on the four basic principles mentioned above. Furthermore, students are expected to respect individuals who choose to practice Islamic teachings at a minimum, moderate and maximum so as not to blaspheme one another in society in the future. Then students are also encouraged to maintain religious emotions so as not to go overboard and get trapped in radicalism that deviates from religion.

In answering this problem, researchers conducted interviews with experts which 
can be described as follows:

Entrepreneurship is the ability to continuously be creative and innovative in business, while entrepreneurship is a person who does business. Therefore, people who do business are not necessarily entrepreneurial and often it causes failure. Indicators in entrepreneurship are building interesting business ideas and providing solutions. In doing business, empathy is also needed. Because by empathy, we can face customers and impress customers. So that, customers do not move to another place. Furthermore, entrepreneurship requires innovation and creativity. By innovation and creativity, business can survive despite many competitors. Finally, the indicator of entrepreneurship is serving people. With good service, we can increase profits because new customers will continue to arrive because of information from loyal customers.

The benefit is to increase the competitiveness of the students. So if students have entrepreneurial skills, then the Islamic boarding schools will not be deserted continuously. Business is in line with the Prophet. Rasulullah has given an example that honesty in business is important. In addition, business ethics, which are sometimes only written on paper, can actually strengthen the business itself. Business ethics can be learned in entrepreneurship. Following business ethics can have a positive impact on the business being run. Business cannot be done alone but involves other people, such as suppliers, customers or distributors. The involvement of these parties creates kinship and of course does not rule out the possibility that the background of our business associates or colleagues is different from ours. The key to religious moderation can be a guide in dealing with business relations or colleagues so that they become familiar and business runs smoothly.

Islamic boarding schools are expected to provide entrepreneurship training to encourage students' abilities in creativity and business innovation. By this training and carried out continuously, the students will have an understanding of the concept of entrepreneurship. Islamic boarding schools can work together with other institutions so that the students' implementation business plan can be realized. By realization of this business plan, students will begin to get to know various customers or potential customers from various backgrounds. So that students know what to do in cooperating with parties of different religions and cultures.

Businesses need the abilities to communicate and relate to other people. These 
relationships often have to be with people of all kinds. To be able to communicate between people of course requires tolerance and respect for each other. Through entrepreneurial indicators as mentioned, such as serving people from various backgrounds with empathy, creative and innovative thinking that encourages attractive business ideas can make students have a competitive edge in society. So that, competitiveness can increase the big name of the Islamic boarding school and encourage the curiosity of others to come.

Entrepreneurship can encourage religious moderation through business ethics content given to students to realize their business plans. Business skills will continue to encourage them to meet different people and communicate to make transactions that benefit both parties. If the students are unable to communicate with various individual backgrounds, their business marketing will be limited and there is a possibility of failure.

From the functions of the Islamic boarding schools that have been shown, the function of the it as a religious institution that carries out social engineering or community development is the most related to the function of empowering the people. Social engineering can be carried out by Islamic boarding schools through entrepreneurship programs.

As has been stated, Islamic boarding schools are advised to open entrepreneurship training so that students can develop business plans. Then in addition to entrepreneurship training, cooperation with economic institutions can encourage the realization of the business plans of the students. This realization is considered to be able to encourage student competitiveness and empower the surrounding community.

\section{CONCLUSION}

Religious moderation in Islamic boarding schools in Jakarta can be enhance with the key of moderation, such as religious knowledge and maintaining religious emotions. In entrepreneurship, there is business ethics content that can provide an overview for students to communicate with potential customers. Prospective customers who come from various backgrounds certainly encourage students to understand the diversity that exists in Jakarta. Through entrepreneurship training and cooperation with professional institutions it can make students realize that moderation is needed to communicate in business. 
Economic empowerment is a function of Islamic boarding schools, namely as a religious institution that carries out social engineering or community development. With the entrepreneurship program, the boarding school has performed a social engineering function or community development. In addition, in entrepreneurship, there is also content of business ethics that encourages students to understand and apply religious moderation.

\section{REFERENCES}

Akhmadi, A. (2019). Moderasi Beragama dalam Keragaman Indonesia. Inovasi: Jurnal Diklat Keagamaan, 13(2), 45-55.

Alfianto, E. A. (2012) Kewirausahaan: Sebuah Kajian Pengabdian Kepada Masyarakat. Jurnal Heritage, 1(2), 33-43.

Alma, B. (2010). Kewirausahaan (Edisi Revisi). Bandung: CV Alfabeta.

Aly, A. (2011). Pendidikan Islam Multikultural di Pesantren. Yogyakarta: Pustaka Pelajar.

Amin, A. R. M. (2014). Prinsip dan Fenomena Moderasi Islam dalam tradisi Hukum Islam. Moderat Islam, Its Principle and Issues in Islamic Law Tradition. Jurnal Al Qalam, 20(3), 23-32.

Aprijon. (2013). Kewirausahaan dan Pandangan Islam. Menara: Jurnal Kewirausahaan, 12(1), 1-11.

Arikunto, S. (2016). Prosedur Penelitian Suatu Pendekatan Praktik. Jakarta: Rineka Cipta.

Awwaliyah, N. M. (2019). Pondok Pesantren Sebagai Wadah Moderasi Islam di Era Generasi Milenial. Islamic Review: Jurnal Riset dan Kajian Keislaman, 8(1), 36-62. DOI 10.35878/Islamicreview.V8i1.161.

Fathoni, M. A., \& Rohim, A. N. (2019). Peran Pesantren Dalam Pemberdayaan Ekonomi Umat di Indonesia. Conference on Islamic Management, Accounting, and Economics (CIMAE) Proceeding, 2(1)134.

Ghofur, A., Asiyah, N., \& Shofiyullah, M. (2015). Pesantren Berbasis Wirausaha (Pemberdayaan Potensi Enterpreneurship Santri di Beberapa Pesantren Kaliwungu Kendal). Dimas: Jurnal Pemikiran Agama untuk Pemberdayaan, 15(2), 19 52. DOI : $10.21580 / \mathrm{dms} .2015 .152 .744$.

Kementerian Agama RI. (2003). Pola Pembangunan Pondok Pesantren. Jakarta: Ditpeka Pontren Ditjen Kelembagaan Agama Islam. 
Kementerian Agama RI. (2012). Moderasi Islam. Jakarta: Lajnah Pentashihan Mushaf AlQur'an.

Maarif, N. H. (2017). Islam Mengasihi Bukan Membenci. Bandung: PT. Mizan Pustaka.

Maesaroh, N., \& Achdiani, Y. (2017). Tugas dan Fungsi Pesantren di Era Modern. Sosietas: Jurnal Pendidikan Sosiologi, 7 (1), 1-20. DOI:https://doi.org/10.17509/sosietas. v7i1.10348.

Mahdi, A. (2013). Sejarah dan Peran Pesantren Dalam Pendidikan di Indonesia. Jurnal Islamic review, 2(1), 346-352.

Misrawi, Z. (2010). Hadratussyaikh Hasyim Asy'ari: Moderasi, Keutamaan, dan Kebangsaan. Jakarta: PT Kompas Media Nusantara.

Moleong, L. J. (2010). Metodologi Penelitian Kualitatif. Bandung: Remaja Rosdakarya.

Muhaimin. (1992). Pemikiran Pendidikan Islam. Kajian Filsafat dan Kerangka Dasar Operasional. Jakarta: Bumi Aksara.

Purwanto, Y., Qowaid., Ma'rifataini L., Fauzi, R. (2019). Internalisasi Nilai Moderasi melalui Pendidikan Agama Islam Di Perguruan Tinggi Umum. Edukasi: Jurnal Penelitian Pendidikan Agama dan Keagamaan, 17(2), 110-124. DOI: http://dx.doi.org/10.32729/edukasi.v17i2.605.

Romadlan, S. (2019). Rekayasa Sosial (Social Engineering) Adopsi Teknologi Komunikasi (Internet) di kalngan Pondok Pesantren Muhammadiyah. Jurnal Lemlit Uhamka, 1(1), 83-91.

Saragih, R. (2017). Membangun Usaha Kreatif, Inovatif dan Bermanfaat Melalui Penerapan Kewirausahaan Sosial. Jurnal Kewirausahaan, 3(2), 26-34.

Sanjaya, W. (2011). Penelitian Tindakan Kelas. Jakarta: Kencana.

Suryana. (2006). Kewirausahaan Pedoman Ppraktis, Kiat dan Proses Menuju Sukses. Jakarta: Salemba Empat.

Sutrisno, H. (2005). Statistik Jilid 2. Yogyakarta: Andi Offset.

Syafrudin. (2009). Paradigma Tafsir Tekstual Dan Kontekstual (Usaha Memaknai Kembali Pesan Al-Qur'an). Yogyakarta: Pustaka Pelajar.

Timmons, J. A. \& Spinelli, S. (2008). New Venture Creation Kewirausahaan untuk Abad 21. Yogyakarta: Andi.

Wahidah, E. Y. (2015). Studi Implementasi Tradisionalisasi dan Modernisasi Pendidikan di Pondok Pesantren. Muaddib: Jurnal Studi Kependidikan dan Keislaman, Vol. 5(2), 184-207. DOI : 10.24269/muaddib.v5i2.70. 
Yahya, A. S. (2017). Ngaji Toleransi. Jakarta: PT Elex Media Komputindo.

Yasid, A. (2014). Islam Moderat. Erlangga. Jakarta.

Yin, R. K. (2013). Studi Kasus: Desain dan Metode. Jakarta: PT. Raja Grafindo Persada.

Zada, K. (2007). Islam Radikal: Pergulatan Ormas-ormas Radikal di Indonesia. Jakarta:Teraju. 